\title{
ДЕРЖАВНА СТРАТЕГІЯ ІННОВАЦІЙ ТА ПРИКЛАДНИЙ ХАРАКТЕР РЕАЛІЗАЦІї ЇХ В НАЦІОНАЛЬНІЙ ЕКОНОМІЦІ
}

\author{
Дейнека О.Г., о.е.н., професор, \\ Заєць Б.М., магістр (УкрДУЗТ)
}

Розглянуто світові тендениії інновачійного процесу та інноваційна діяльність підприємств України. Розкриті проблеми, які гальмують розвиток інновачійних процесів в національній економіці. Запропоновані основні напрямки, технології формування і управління інновачійним потенціалом, охарактеризовано можливості застосування в Украйні міжнародного досвіду у иій сфері.

Ключові слова: інновацї, інноваційна діяльність, інноваційні процеси, інноваційна інфраструктура, інноваційний потенціал, інноваційна політика.

\section{ГОСУДАРСТВЕННАЯ СТРАТЕГИЯ ИННОВАЦИЙ И ПРИКЛАДНОЙ ХАРАКТЕР РЕАЛИЗАЦИИ ИХ В НАЦИОНАЛЬНОЙ ЭКОНОМИКЕ}

\author{
Дейнека О.Г., о.э.н., профессор, \\ Заец Б.Н., магистр (УкрГУЖТ)
}

\begin{abstract}
Рассмотрены мировые тенденщии инноваџионного прочесса и инноваџионная деятельность предприятий Украины. Раскрыты проблемы, которые тормозят развитие инновачионных процессов в национальной экономике. Предложены основные направления, технологии формирования и управления инновационным потенциалом, охарактеризованы возможности применения в Украине международного опыта в этой сфере.

Ключевые слова: инновации, инновационная деятельность, инновационные процессы, инновационная инфраструктура, инновационный потенциал, инновационная политика.
\end{abstract}

\section{THE STATE STRATEGY OF INNOVATIONS AND THE APPLIED NATURE OF THEIR IMPLEMENTATION IN THE NATIONAL ECONOMY}

\author{
Dejneka O.G., Doctor of Economic Sciences, Professor, \\ Zaetsh B.N., master (USURT)
}

Competitiveness of the global market is increasingly dependent on products based on which new knowledge lies. Today the industry needs science, innovations, education. The development of productive forces occurs with the close interaction of science and the latest technology.

An analysis of the current state of the Ukrainian economy has shown that the existing decline and stagnation in industry can not be overcome by traditional methods, as it was possible in the near past. There is a need for radical measures for the introduction of new 
technical and technological solutions, modern production processes, capable of producing competitive products and providing competitive services. The above will allow the economy to exit the protracted crisis and provide Ukraine with a worthy place in the world community. Therefore, this direction of scientific research, namely the strategic aspect of innovation processes in Ukraine on the basis of foreign experience, is considered relevant.

In a market economy, the company's successful activity is provided by innovation policy, which is the decisive tool in the competitive struggle.

The main task of the state innovation policy should be measures aimed at creating conditions for the organic combination of scientific and technological and entrepreneurial environment.

The state should strengthen direct support for the innovation process in promoting the creation of innovation infrastructure, the formation of scientific and production associations, etc. But only significant innovations should be encouraged by the state financially, for example, through preferential taxation or at the expense of budget allocations. This approach will allow not to spill out state funds in support of unpredictable innovations and will promote innovations aimed at economic breakthrough and sustainable growth. Market mechanisms at the present stage will not be enough for a noticeable intensification of the innovation process in Ukraine.

The world tendencies in the field of technology development, at first glance, seem far from Ukrainian reality and do not significantly affect the range of domestic commodity producers. However, the desire of Ukraine to become a full member of the international trading system requires the production of goods and services in accordance with world requirements. That is why we need to talk about the innovative development of Ukraine not only from the point of view of raising the level of competitiveness and protection of domestic commodity producers, but also from the point of view of the expansion of our country to foreign markets.

Key words: innovation, innovation, innovation processes, innovation infrastructure, innovation potential, innovation policy.

\section{Постановка проблеми.}

Загальновідомо, що рівень розвитку країни залежить від рівня розвитку інноваційної діяльності, тому впровадження інновацій $\epsilon$ головним чинником успіху підприємства, який впливає i на економічний стан держави загалом.

Конкурентоспроможність па світовому ринку все більше залежить від продукції, в основі якої лежать нові знання. Сьогодні індустрія має потребу в науці, нововведеннях, освіті. Розвиток продуктивних сил відбувається при тісній взаємодії науки і новітніх технологій.

Аналіз сучасного стану економіки України показав, що існуючий занепад i застій у промисловості неможливо перебороти традиційними методами, як це було можливим ще в недалекому минулому. Необхідні радикальні заходи для впровадження нових технічних i технологічних рішень, сучасних виробничих процесів, здатних випускати конкурентоспроможні товари та надавати конкурентоспроможні послуги. Зазначене дасть змогу економіці вийти з затяжної кризи і забезпечити Україні гідне місце у світовому співтоваристві. Тому зазначений напрямок наукових досліджень, а саме стратегічний аспект інноваційних процесів в Україні на основі зарубіжного досвіду вважається актуальним.

Аналіз останніх досліджень i публікацій. Питання інноваційного розвитку України доволі активно досліджують вітчизняні науковці. Так, у статтях Ж. Говорухи [4], А. Чухно [6], I. Космидайло [11] розглянуто проблеми та перспективи розвитку інноваційної діяльності в країні. У працях 
М. Денисенка, Т. Воронкової, С. Ладика [10], М. Жук [7] проаналізовано загальний інноваційно-технологічний стан України та запропоновано моделі національної інноваційної політики. Можливі залучення інвестицій та фінансування інноваційної сфери державою розглядають у своїх роботах Н. Гончарова [5], О. Паливода [8].

Питання стратегії інноваційного розвитку досліджують вчені Українського державного університету залізничного транспорту. Зокрема це В. Дикань, О. Дейнека, Л. Позднякова, Ю. Калабухін та інші [13] [14] [15] [16].

Однак, треба зазначити, що механізм можливого використання зарубіжного досвіду управління інноваційними процесами $€$ менш дослідженим та потребує детальнішого розгляду.

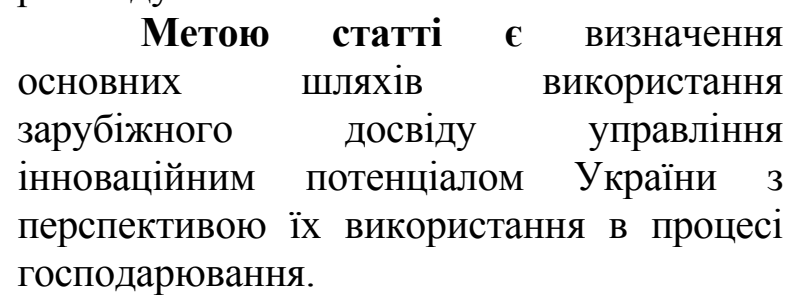

Виклад основного матеріалу. Світові тенденції інноваційного процесу та інноваційна діяльність підприємств України.

В умовах ринкової економіки успішну діяльність підприємства забезпечує інноваційна політика, яка $\epsilon$ визначальним інструментом у конкурентній боротьбі.

Безумовними лідерами у виробництві світової наукової продукції $\epsilon$ США і Японія. Вважається, що приблизно $80 \%$ усіх світових інновацій створюється в США. Витрати США на науково-дослідні і дослідно-конструкторські роботи (НДДКР) перевищують витрати Англії, Франції, ФРН та Італії разом узятих і становлять понад половину витрат на НДДКР розвинених країн. Така увага до НДДКР привела до того, що в США продається 90 \% нових товарів і тільки $10 \%$ старих, що надійшли на ринок більше як 5 років тому.
Другою світовою державою, що здійснює величезні витрати на новації, $є$ Японія. За цими витратами на душу населення вона знаходиться на одному рівні зі США. Якщо раніше Японія багато інновацій запозичала із Заходу та колишнього СРСР, то сьогодні вона вийшла на перше місце у світі 3 виробництва суден, автомобілів, тракторів та іншої техніки [1].

Особливістю

інноваційного

процесу, який став однією 3 головних тенденцій світового розвитку, починаючи 3 70-х років XX ст. і продовжується й зараз, $\epsilon$ те, що основним творцем та розробником науково-технічної продукції стають малі науково-технічні фірми, які ще називають венчурними фірмами. Венчурні фірми - це, як правило, малі підприємства в наукомістких галузях економіки, що спеціалізуються в галузі наукових досліджень, інженерних розробок, створення і впровадження нововведень.

Іншою помітною тенденцією треба вважати симбіоз академічної науки i промисловості та виникнення на його основі широкої мережі технопаркових структур. Зараз загальна кількість технопарків у світі становить кілька тисяч. У США діє 140 технопарків, в Свропі - 260 [2].

Третьою тенденцією розвитку світової економічної системи є посилення державної підтримки тим суб'єктам, які займаються інноваційною діяльністю.

Унаслідок зазначених тенденцій у розвинених країнах більше половини підприємств займаються інноваційною діяльністю.

В Україні ситуація є протилежною. На тлі гучних декларативних заяв про підтримку i розвиток інноваційного процесу в Україні реальна ситуація свідчить зовсім про інше. Питома вага підприємств, що займаються інноваційної діяльності, є у 20-30 разів меншою, ніж у розвинених країнах, крім того, цей показник має тенденцію до зниження. 
Перехід української економіки до ринкових відносин супроводжується всезростаючим науково-технічним i технологічним відставанням від індустріально розвинених країн [1]. Причина цього - відсутність стабільної стратегії розвитку країни, що спричинило нестабільність і ситуативність економічних процесів. Нехтування сучасними тенденціями розвитку світової економіки може обумовлювати те, що Україна в найближчій перспективі буде повністю витіснена із ринку високотехнологічної продукції, а це безпосередньо вплине на рівень соціально-економічного стану країни та погіршення якості життя населення.

Незважаючи на те, що протягом останніх років чисельність науковотехнічних працівників в Україні зменшилася вдвічі, країна ще має потужний науковий потенціал, здатний виконувати складні фундаментальні та прикладні дослідження, багатогалузевий промисловий комплекс, на $30 \%$ зорієнтований на високотехнологічне виробництво (машинобудування, приладобудування, енергетика, авіаційні та космічні технологіiі) [7].

Україна відома у світі своїми видатними вченими, науковими колективами та наукомісткими виробництвами. Проблема полягає тільки в тому, як всім цим розпорядитися.

До головних чинників, що гальмують інноваційну діяльність в Україні, можна віднести:

- відсутність достатніх джерел фінансування;

- недосконалість законодавчої

бази у сфері інновацій, податкової системи;

- відсутність пільгового режиму для здійснення інноваційної діяльності;

- міграція фахівців високого рівня, науковців у США, Німеччину та інші країни;

- відсутність інформації та технологічної бази.
Ситуація, що склалася, терміново потребує виправлення, при цьому істотну допомогу може надати врахування світового досвіду організації інноваційного процесу.

Іноземний досвід державного регулювання інноваційних процесів: висновки для України.

Сьогодні серед розвинених країн немає такої, де держава тими чи іншими методами не прагнула б сприяти інноваційному процесу.

Аналізуючи державну політику розвинених країн щодо підтримки інновацій за ступенем державного регулювання, можна виділити два полюси. На одному знаходяться США та Велика Британія, де держава найменше втручається в економіку, зокрема й в інноваційну діяльність, на іншому Франція та Японія, в яких держава найбільш активно підтримує інноваційний процес всіма можливими методами [3].

Перший полюс, який умовно можна назвати англо-американською моделлю, характеризується найповнішою автономією підприємництва в інноваційній сфері. За такої моделі вважається, що ринкові механізми самі сприяють прискоренню інноваційного процесу. Головний акцент робиться на створення сприятливих умов для ведення бізнесу взагалі, що зумовлює рівні умови для впровадження інноваційних продуктів у всі галузі народного господарства.

Другий (франко-японський) полюс інноваційної політики характеризується досить значним впливом держави на інноваційні процеси, зокрема i неринковими методами, шляхом прямих дотацій i субсидій підприємствам i організаціям, які здійснюють інноваційну діяльність. За цієї моделі уряди визначають пріоритетні напрямки інноваційнотехнологічного розвитку, яким надається суттєва урядова підтримка.

Більшість розвинених європейських країн та Канада займають проміжне положення між зазначеними полюсами 
інноваційної політики, одночасно розвиваючи національне бізнессередовище i використовуючи пряму державну підтримку інноваційної діяльності [3-6].

3 посиленням міжнародних інтеграційних процесів і виробленням погодженої економічної політики у загальному економічному просторі країн, зокрема членів $\mathrm{CC}$, з'являється нова можливість - розроблення єдиної інноваційної політики на рівні державчленів співтовариства.

Аналізуючи все вищезазначене, можна зробити висновок, що за різноманіттям форм i прийомів стимулювання інноваційної діяльності 3 боку державних органів, у всіх промислово розвинених країнах прослідковується дещо загальне, що дає змогу виділити інноваційну політику як специфічний елемент системи державного регулювання. Так, відзначається погодженість інноваційної політики 3 усіма видами державної економічної політики взагалі $[8,9]$.

На наш погляд, не можна сказати, що та чи інша модель підтримки інноваційного процесу $є$ кращою. Вибір спрямованості державної політики залежить від багатьох чинників та особливостей інноваційного розвитку. Тоді як українська економіка намагалася вийти 3 кризи, застосовуючи традиційні технології, промислово розвинені країни спрямували свої зусилля на створення нової економіки, заснованої на знаннях, інформації та інноваціях. Сьогодні, маючи достатньо високий науково-технологічний потенціал, Україна недостатньо використовує його в національних інтересах. Українську інноваційну політику, яка все ще перебуває на стадії формування, можна кваліфікувати як таку, що тяжіє до англо-американської моделі, оскільки держава більше покладається на ринкові механізми стимулювання інноваційної діяльності, ніж на пряму підтримку інноваційного процесу. Але проблема полягає не в тому, що розвиток науки i науково-технічних розробок практично не фінансується державою, а в тому, що наука i економіка України розвиваються різними шляхами. Більшість розробок, виконаних вітчизняними науковцями, не мають практичного застосування у жодній галузі економіки країни. Це спричиняє фактичну ізольованість наукових установ від підприємництва, а отже, унеможливлює розвиток інноваційного процесу за рахунок ринкових важелів, оскільки інноваційна діяльність опинилася значною мірою поза межами ринку.

Тобто, основним завданням державної інноваційної політики мають бути заходи, спрямовані на створення умов для органічного поєднання науковотехнологічного i підприємницького середовища.

Держава має посилити пряму підтримку інноваційного процесу у вигляді сприяння створенню інноваційної інфраструктури, становленню наукововиробничих об'єднань тощо, але лише істотні нововведення держава повинна заохочувати фінансово, наприклад, через пільгове оподаткування або за рахунок бюджетних асигнувань. Такий підхід дасть змогу не розпилювати державні кошти на підтримку малоперспективних нововведень i сприятиме інноваціям, спрямованим на економічний прорив i забезпечення стійкого зростання. Ринкових механізмів на сучасному етапі буде недостатньо для помітної інтенсифікації інноваційного процесу в Україні.

Шляхи використання зарубіжного досвіду управління інноваційним потенціалом в Україні.

Перетворення технологій $\mathrm{y}$ головний ресурс сучасного економічного розвитку та управління ними радикально змінюе всю систему свідомих дій i поведінку України як суб'єкта світового ринку. Тому є необхідним використання зарубіжних форм управління інноваційними процесами, які $\epsilon$ 
недостатньо поширеними в Україні, а саме: стратегії технологічного розвитку підприємств, конкурсно-контрактна система створення науково-технічної продукції, напрямки розвитку інноваційної інфраструктури та державного регулювання інноваційної діяльності. Розглянемо ці аспекти детальніше.

Стратегії технологічного розвитку підприємств. Аналіз досвіду країн, які досягли найвагоміших успіхів у науковотехнологічному розвитку, експорті наукомісткої і високотехнологічної продукції дає змогу виділити такі стратегії технологічного розвитку підприємств: стратегія «нарощування», стратегія «запозичення», стратегія «міжнародної кооперації».

Основою стратегії "нарощування" $€$ технологічний ізоляціонізм. Цей вид стратегії використовують лише деякі, як правило, дуже великі компанії, які володіють величезними технологічними фінансово-економічними і організаційними можливостями. Створені в них могутні науково-дослідні структури забезпечують технологічне лідерство у випуску масового товару, що визначає іх спрямованість на технологічну відособленість і вибір стратегії нарощування конкурентних переваг за рахунок власного науковотехнічного потенціалу. Однак, в Україні відсутні такі віолентні структури. Це пояснюється тим, що основними споживачами високотехнологічних продуктів спеціалізованих підприємств були військово-промисловий комплекс, електрона промисловість i загальне машинобудування, тобто галузі, які після розпаду СРСР опинилися на межі виживання. Тому застосування цієї стратегії в нашій країні $є$ дуже складним та капіталомістким.

Стратегія "міжнародної кооперації" полягає у придбанні підприємствами країни зарубіжних модифікованих або радикальних технологій на основі використання різних форм міжнародного науково-технологічного i виробничого співробітництва.

Найефективнішою формою міжнародної технічної взаємодії $€$ розвиток спільного підприємництва.

На кінець 2006 р. в Україні було зареєстровано понад 5000 спільних підприємств (СП), серед яких лише 17 \% господарюють у сфері виробництва, а обсяг випуску їх продукції становить лише 3 \% вітчизняного ВВП. На думку фахівців, використання СП у розвитку пріоритетних галузей i виробництв промисловотехнологічної сфери України вимагає суттєвого вдосконалення нормативноправової бази іноземного інвестування в Україні та системи управління, що пов'язано, насамперед, із посиленням регуляторної ролі держави та відповідальності суб'єктів господарювання [2-4].

Стратегія "запозичення" полягає у використанні власної дешевої робочої сили i науково-технологічного потенціалу країни для освоєння випуску нових машин i обладнання, які виготовляються у розвинених країнах, технологічні процеси яких можуть бути скопійовані зі зразка. На мою думку, саме ця стратегія $\epsilon$ найактуальнішою та доступною для України на сучасному етапі іï економічного розвитку.

Конкурсно-контрактна система створення науково-технічної продукції. Конкурсно-контрактна система створення науково-технічної продукції дуже поширена на Заході. Вона дає змогу ефективно використовувати кошти, призначені для реалізації науковотехнічних програм. Залучення до складу конкурсної комісії висококваліфікованих експертів дає змогу об'єктивно встановити науково-технічний рівень i можливості тих, хто претендує на отримання замовлень щодо створення науково-технічної продукції, обрати на альтернативній основі розробника, який забезпечить оптимальні параметри розробки.

Участь у конкурсі можуть взяти всі бажаючі (відкритий конкурс) або заздалегідь визначені замовником 
організації (закритий конкурс). Усі учасники конкурсу повинні знаходитися у рівних умовах.

При оцінці пропозицій учасників конкурсу незалежні експерти беруть до уваги як техніко-економічні параметри розробки, так і організаційно-комерційні умови (вартість, терміни, ціна робіт, можливості залучення кваліфікованих субпідрядників, надійних постачальників). Всі учасники сповіщаються про прийняття або відхилення їхніх пропозицій у письмовому вигляді.

Взаємовідносини замовника i розробника оформляють шляхом укладання контрактів на проведення відповідних НДЦКР [10,11].

Подібний конкурс був проведений в Україні у 2005 p. під назвою «Отечественные прикладные научнотехнические разработки для малого и среднего бизнеса». Однак, він не мав державної підтримки. Тому треба зазначити, що досягнення синергічного ефекту стає можливим тільки за умови взаємодії між державою, суспільним та підприємницьким секторами. Вони мають бути скеровані на розвиток всього суспільства через створення життєздатного потрійного союзу між розробниками, промисловцями і підприємцями України і інвесторами, зокрема зовнішніми.

Інноваційна інфраструктура. При формуванні нової моделі національної інноваційної системи, одну 3 ключових ролей відіграє інноваційна інфраструктура, яка забезпечує горизонтальні і вертикальні зв'язки між суб'єктами інноваційної діяльності, сприяє прискоренню трансферу знань і дифузії технологій.

Однією $з$ таких форм управління $\epsilon$ менеджмент циклу «наука-технікавиробництво», до якої зокрема належать так звані технопарки, технополіси й інкубатори.

Особливе місце, на наш погляд, в інноваційній інфраструктурі займають бізнес-інкубатори. У сучасному світі бізнес-інкубатором прийнято вважати інноваційну структуру, що має своєю метою підтримку утворення i розвитку нових організацій шляхом надання їм площ для оренди, первісного капіталу, консультацій i т.п. Відомі випадки об'єднання декількох успішно працюючих бізнес-інкубаторів у нову структуру технопарк.

Наступний рівень у розвитку інноваційної структури - технополіс. Він зазвичай виникає там, де переплітається діяльність сусідів-технопарків. Щодо розвитку цих структур в Україні, вони можуть бути створені на базі великих науково-промислових центрів (Київ, Харків, Дніпро, Одеса, Львів), де існують могутні науково-виробничі комплекси із збалансованого розвитку регіональної економіки.

В Україні утворена активно діюча Асоціація бізнес-інкубаторів. Налагоджено інтенсивний процес обміну інформацією щодо концепцій інноваційного бізнесу i менеджменту 3 фахівцями із США, які мають на меті дати молодим українським дослідникам та інженерам інформацію, пов'язану 3 дифузією технологій 3 лабораторій на ринок.

\section{Вивчаючи досвід створення} інноваційних структур у країнах 3 перехідною економікою, треба зазначити, що створення бізнес-інкубатора, а тим більше технопарку є складною, дорогою i довгостроковою справою. Але воно дуже перспективне для України, тому що має стратегічне значення, вектор орієнтації якого спрямований у технологи XXI ст. Але не можна очікувати від них миттєвої віддачі. Наприклад, досвід Росії показує, що період становлення i досягнення апогею діяльності технопарку становить 810 років [1, 12]. Сьогодні Україна робить перші кроки на шляху інноваційного розвитку. I технопарки при цьому грають найважливішу роль як піонерські структури, що дають змогу за недостатнього державного фінансуванні використовувати механізми цільового використовування засобів, одержуваних 
при виконанні інноваційних проектів, для розвитку власних наукових баз за рахунок принципу реінвестування, що $є$ сьогодні єдиною можливістю підтримки і розвитку як науково-технологічного потенціалу, так і інноваційної діяльності в країні.

Очевидно, що подальше становлення i розвиток мережі бізнесінкубаторів, наукових i технологічних парків в Україні визначатиметься як об'єктивними труднощами перехідного до ринкових умов господарювання періоду, так i національними особливостями реалізованої економічної моделі стимулювання інновацій.

Висновок. Світові тенденції в області розвитку технологій, на перший погляд, видаються далекими від української дійсності та такими, що істотно не впливають на дальність вітчизняних товаровиробників. Проте прагнення України стати повноцінним членом міжнародної торгової системи вимагає виробляти товари і послуги відповідно до світовими вимогами. Саме тому потрібно вести мову про інноваційний розвиток України не тільки 3 позиції підвищення рівня конкурентоспроможності та захисту вітчизняних товаровиробників, а i 3 позицій експансії нашої країни на зовнішні ринки.

Вищезазначені тенденції повинні обов'язково враховуватися сучасними українськими компаніями і державою під час розроблення та впровадженні інноваційних технологій, продуктів на ринок.

Інноваційна політика повинна грунтуватися на пріоритетах економічної політики, зокрема:

- концентрація ресурсів на проведенні фундаментальних і прикладних досліджень в тих напрямках, де Україна має значний науковий, технологічний i виробничий потенціал;

- впровадження програмно-

цільового підходу до фінансування всіх секторів наукової сфери; впровадження ринкових

механізмів підтримки нових технологій, розширення участі малого i середнього бізнесу в науково-технологічному розвитку;

- приведення системи правового захисту інтелектуальної власності у відповідність 3 міжнародними нормами і введення інтелектуальної власності в господарський оборот;

- розвиток і впровадження

сучасних інформаційних технологій;

- подолання надвитратності, неприпустимо високої енерго- i матеріаломісткості всієї нашої промисловості;

пріоритетна підтримка інноваційного розвитку галузей економіки, які вже зараз можуть вийти на світовий ринок;

- інтеграція в міжнародні технологічні потоки 3 метою модернізації вітчизняного виробництва;

- запобігання надходження до України застарілих i малоефективних технологій.

Розвиток інноваційної діяльності один 3 основних шляхів виходу економіки України $з$ кризової ситуації і отримання високого рівня прибутку. При цьому важливо враховувати світовий досвід організації інноваційного процесу.

Подальші дослідження доцільно проводити в напрямку розроблення досконаліших засобів стимулювання інноваційних процесів у національній економіці. Посилення державної підтримки інноваційної діяльності підприємств України вимагає створення ефективних механізмів взаємодії органів влади 3 підприємствами, що займаються інноваціями, залучення їх до розроблення проектів нормативних актів, співучасті в роботі конференцій, робочих груп тощо.

\section{ПЕРЕЛІК ВИКОРИСТАНИХ ДЖЕРЕЛ}

1. Василенко В.О., Інноваційний менеджмент / В.О. Василенко, В.Г. 
Шматько - .: Центр навчальної літератури, 2005. - 440 с.

2. Соціально-економічне становище України за 2003 р. // Економіст. -2004. №1. - C.6-11.

3. Ганущак Л.М. Шляхи використання зарубіжного досвіду управління інноваційним потенціалом підприємств в Україні / Л.М. Ганущак // Актуальні проблеми економіки. - 2006. №4(58). - С. 135-142.

4. Говоруха Ж.А. Питання розвитку інноваційної діяльності підприємств України/ Ж.А. Говоруха // Актуальні проблеми економіки. - 2007. - №8 (74). C. $107-115$.

5. Гончарова Н.В. Напрями розвитку інтеграційних процесів у сфері фінансової підтримки малого підприємництва / Н.В. Гончарова // Фінанси України. 2003. - C.75-83.

6. Чухно А. Актуальні проблеми стратегії економічного та соціального розвитку на сучасному етапі / А. Чухно // Економіка України. - 2004. - №4. - С.65 71.

7. Жук М.В. Передумови формування національної інноваційної системи прискореного розвитку економіки / М.В. Жук // Актуальні проблеми економіки. - 2008. - №7 (85). - С.30-36.

8. Паливода О.М. Критерії оцінки інновацій для вибору форм i методів державної підтримки / О.М. Паливода // Актуальні проблеми економіки. -2008. №3 (81). - С.38 - 42.

9. Федулова Л. Перспективи інноваційно-технологічного розвитку промисловості України / Л. Федулова // Економіка України. - 2008. - №7. - С. 2436.

10. Денисенко М.П. Проблеми формування національної інноваційної системи України / М.П.Денисенко, Т.Є.Воронкова, С.В. Ладика // Актуальні проблеми економіки. - 2008. - №4 (82). С.73-81.

11. Космидайло I.В. Проблеми інноваційного розвитку в Україні та шляхи їх вирішення / І.В. Космидайло // Актуальні проблеми економіки. - 2007. №2 (68). - С.20-27.

12. Гончаров Н.П. Теоретикометодические аспекты формирования инновационной политики / Н.П. Гончаров // Актуальні проблеми економіки. - 2008. №4 (82). - С.63-72.

13. Дикань В.Л. Стратегічне управління : навч.посіб. / В.Л. Дикань, В.О. Зубенко, О.В. Маковоз, I.В. Токмакова, О.В. Шраменко - К.: центр учбової літератури, 2013, 272 с.

14. Дикань В.Л. Удосконалення механізмів державного управління розвитком залізничної галузі України в євро інтеграційному векторі / В.Л.Дикань, Г.Є. Островерх // Вісник економіки транспорту і промисловості. - 2018. - № 62. - C.11-20.

15. Дейнека О.Г. Формування стратегії інноваційного розвитку для підприємств залізничного транспорту в умовах формування швидкісного руху / О.Г.Дейнека, Ю.С.Камчатна // Вісник економіки транспорту і промисловості. 2018. - № 62.- C.174-180.

16. Позднякова Л.О. Удосконалення мотивації праці у зв'язку з впровадженням швидкісного та високошвидкісного руху / Л.О.Позднякова, Н.П. Груця // Вісник економіки транспорту промисловості. 2018. - 63. - C. 127-133.

\section{REFERENCES}

1. Vasylenko V.O., Shmatjko V.Gh. (2005) Innovacijnyj menedzhment [Innovation management]. $\mathrm{K}:$ : Center for Educational Literature. (in Ukrainian)

2. Socialjno-ekonomichne stanovyshhe Ukrajiny za 2003 r. [Socio-economic situation of Ukraine in 2003]. Economist. No. 1, pp. 6-11

3. Ghanushhak L.M. (2006) Shljakhy vykorystannja zarubizhnogho dosvidu upravlinnja innovacijnym potencialom pidpryjemstv $\mathrm{v}$ Ukrajini [Ways of using foreign experience in managing the 
innovative potential of enterprises in Ukraine]. Actual problems of the economy. No. 4(58), pp. 135-142

4. Ghovorukha Zh.A. (2007) Pytannja rozvytku innovacijnoji dijaljnosti pidpryjemstv Ukrajiny [Issues of development of innovation activity of enterprises of Ukraine]. Actual problems of the economy. No 8(74), pp. 107-115.

5. Ghoncharova N.V. (2003) Naprjamy rozvytku integhracijnykh procesiv $\mathrm{u}$ sferi finansovoji pidtrymky malogho pidpryjemnyctva [Areas of development of integration processes in the field of financial support of small business]. Finance of Ukraine. pp. 75-83.

6. Chukhno A. (2004) Aktualjni problemy strateghiji ekonomichnogho ta socialjnogho rozvytku na suchasnomu etapi [Current problems of the strategy of economic and social development at the present stage]. Ukraine economy. No 4, pp. $65-71$.

7. Zhuk M.V. (2008) Peredumovy formuvannja nacionaljnoji innovacijnoji systemy pryskorenogho rozvytku ekonomiky [Prerequisites for the formation of a national innovation system for accelerated economic development]. Actual problems of the economy. No 7 (85), pp. 30-36.

8. Palyvoda O.M. (2008) Kryteriji ocinky innovacij dlja vyboru form i metodiv derzhavnoji pidtrymky [Criteria for assessing innovation to select forms and methods of government support]. Actual problems of the economy. No 3 (81), pp. 38 - 42.

9. Fedulova L. (2008) Perspektyvy innovacijno-tekhnologhichnogho rozvytku promyslovosti Ukrajiny [Perspectives of innovation and technological development of industry of Ukraine]. Ukraine economy. No.7, pp. 24-36.

10. Denysenko M.P., Voronkova T.Je., Ladyka S.V. (2008) Problemy formuvannja nacionaljnoji innovacijnoji systemy Ukrajiny [Problems of formation of the national innovation system of Ukraine]. Actual problems of the economy. No 4 (82), pp. 73-81.
11. Kosmydajlo I.V. (2007) Problemy innovacijnogho rozvytku $\mathrm{v}$ Ukrajini ta shljakhy jikh vyrishennja [Problems of innovation development in Ukraine and ways of their solution]. Actual problems of the economy. No 2. (68), pp. 20-27.

12. Ghoncharov N.P. (2008) Teoretykometodycheskye aspektы formyrovanyja ynnovacyonnoj polytyky [Theoretical and methodical aspects of the formation of innovation policy]. Actual problems of the economy. No. 4 (82), pp. 63-72.

13. Dykan V.L., Zubenko V.O., Makovoz O.V., Tokmakova I.V., Shramenko O.V. (2013) Strateghichne upravlinnja : navch.posib [Strategic Management: Teachers]. K.: Center for Educational Literature. (in Ukrainian)

14. Dykan V.L., Ostroverkh Gh.Je. (2018) Udoskonalennja mekhanizmiv derzhavnogho upravlinnja rozvytkom zaliznychnoji ghaluzi Ukrajiny $\mathrm{v}$ jevro integhracijnomu vektori [Improvement of the mechanisms of state governance for the development of the railway industry of Ukraine in the euro integration vector]. The bulletin of Transport and Industry Economics. No. 62, pp. 11-20.

15. Dejneka O.Gh., Kamchatna Ju.S. (2018) Formuvannja strateghiji innovacijnogho rozvytku dlja pidpryjemstv zaliznychnogho transportu $\mathrm{v}$ umovakh formuvannja shvydkisnogho rukhu [Formation of the strategy of innovative development for enterprises of railway transport in conditions of formation of highspeed traffic]. The bulletin of Transport and Industry Economics. No. 62, pp. 174-180.

16. Pozdnjakova L.O., Ghrucja N.P. (2018) Udoskonalennja motyvaciji praci u zv'jazku z vprovadzhennjam shvydkisnogho ta vysokoshvydkisnogho rukhu [Improvement of labor motivation in connection with the introduction of highspeed and high-speed traffic]. The bulletin of Transport and Industry Economics. No 63, pp. 127-133. 